\title{
The development of the principles of the Elements of Islamic architectural by using parametric algorithms
}

\author{
Presented by Arch/Sara Mahmoud Ahmed Fouad, Architecture Department \\ Prof. Dr.: Mohammed Alaa Mandour, Architecture department, Faculty of Engineering - Mattariah \\ Assoc. Prof. Dr.: Sahar Morsy Mohammed, Architecture department, Faculty of Engineering - \\ Mattariah
}

\begin{abstract}
Islamic architecture represents a great civilization that passed through it, Architects constructed many buildings in different parts of the world. It is one of the most important Aspects of civilization that characterized Islamic history for decade, because it is rich in vocabulary, details and environmental treatments that move towards contemporary architecture.

But with the transformation of the architectural form of Islamic architecture by using parametric algorithms the principles of Islamic architecture had changed and new principles had appeared and some had neglected so we are going to obtain these principles to develop the Islamic architecture into parametric Islamic architecture.
\end{abstract}

Keywords: Islamic architecture, parametric architecture, Islamic parametric patterns, Islamic elements.

\section{Introduction}

In ancient times; Islamic architecture emerged in the Arabian Peninsula and spread east and west with the Islamic conquests covering a vast area of land. Within each country entered by the Muslims, many buildings are built, most of which adhered to the content of Islamic thought. Egypt received architectural and artistic groups from different successive civilizations for its rule in different Islamic eras from the Islamic conquest from $641 \mathrm{AD}$ to $1878 \mathrm{AD}$. These monuments of all purposes are seen between mosques, schools, hospitals, khanqat, sabil, palaces, baths, wekalats, walls and citadel. Today Islamic architecture is one of the most important aspects of civilization, which has characterized Islamic history for decades, during which architects have created artifacts in different parts of the world ${ }^{(1)}$.

\section{2-Stages of development of Islamic architecture in Egypt}

Many developments had happened to Islamic architecture through each era. In Umayyad era in Egypt: The Mosque of Amr ibn al-Aas had extended and renewed several times, four silos had built above the four corners, the first minarets, mihrab hollow, baths, markets, domes and mosques had built in Egypt. The Abbasid era affected by Sassanian architectural styles in using bricks and gypsum in covering the buildings. Then the Ibn Tulun Mosque was built. In State of Echidism: The internal revolutions increased in the country and were no longer in any significant way. The Fatimid had built the arches surrounding the courtyard, the higher ceilling Corridors and arches which is higher than the level of the Iwan. Jouhar had built an exterior wall with seven doors and Al-Azhar Mosque. In the Ayyubid State the schools were built. The development of the construction of fences, fortresses, castles and the most of its buildings were built from bricks while mosques, schools, and their houses were built from sculpted stone. In The Mamluk Period Magmoaat Qalawun and Sultan Hassan School were built.The most important Mamluk palaces large tombs were built by Prince Bashtak. In the Ottoman Period: The 
church of Aya Sophia had turned into a mosque and added 4 minarets. The four iwans schools had disappeared. The markets and Wakalah also had increased in number ${ }^{(2)}$.

\section{3- Types of Islamic buildings}

The main feature that were prominent in Islamic architecture is the Mosque. The other types are tekya and khanaqat, el wekala, gates and fences, houses and palaces. The Mosque was the main features prominent in Islamic architecture included a mihrab, minarets, domes and arches. Al Tekya is an open square courtyard surrounded by four shaded corridors, and behind each corridor there are rooms of residential Sufi. Khanaqa contains a courtyard surrounded by orthogonal iwans which are perpendicular to the square courtyard. In the corners of this box are the Sufi rooms. El Wekala: The ground floor contains a number of "stores" and opens on a shaded corridor that separates them from the middle courtyard. Gates and Fences: The city of Cairo was founded, with a defensive wall, the Fatimids built a second wall around Cairo, had a significant number of fortified gates. Citadel: One of the most important castles built by Salah al-Din. It consists of two main sections, the northern section, which is a rectangular military fort with towers, and the south-west section with accessories from palaces, mosques and stables. Houses and Palaces: It have been characterized in their composition and engineering, very harmonious with the climate conditions. Had an inner courtyard contain fountain, used internal windows bigger than external ${ }^{(3)}$.

\section{4- Characteristics of Islamic buildings}

Islamic architecture was characterized by using elements and decorative patterns in a unique manner to produce magnificent structure. These elements such as: Gates, Entrances and Doors, Windows, Mashrabiyat, Qibla and Mihrab,Al Minbar, Columns, the arches, minarets, Domes, Roofs, Arays, Fountains, Moquarnas and Arabisque.

\section{(4/1) Analysis of The Elements of the Islamic architectural form through eras}

Islamic architecture took the appropriate for it as it is or developed in a manner that does not contradict the Islamic faith and has continued so far suitable for man and place and time because they have an architectural thought that is not associated with a specific time or certain elements ${ }^{(4)}$. 


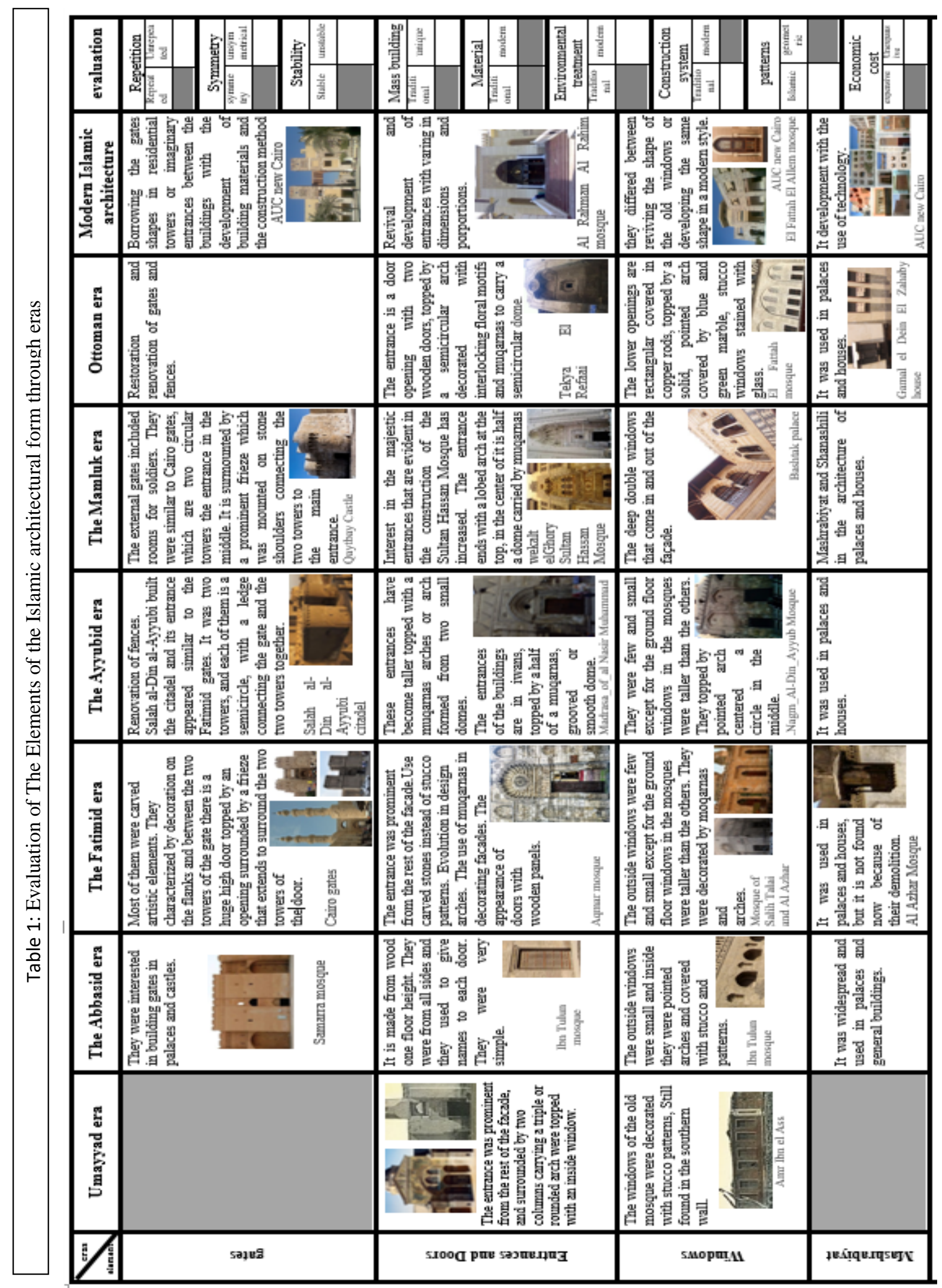




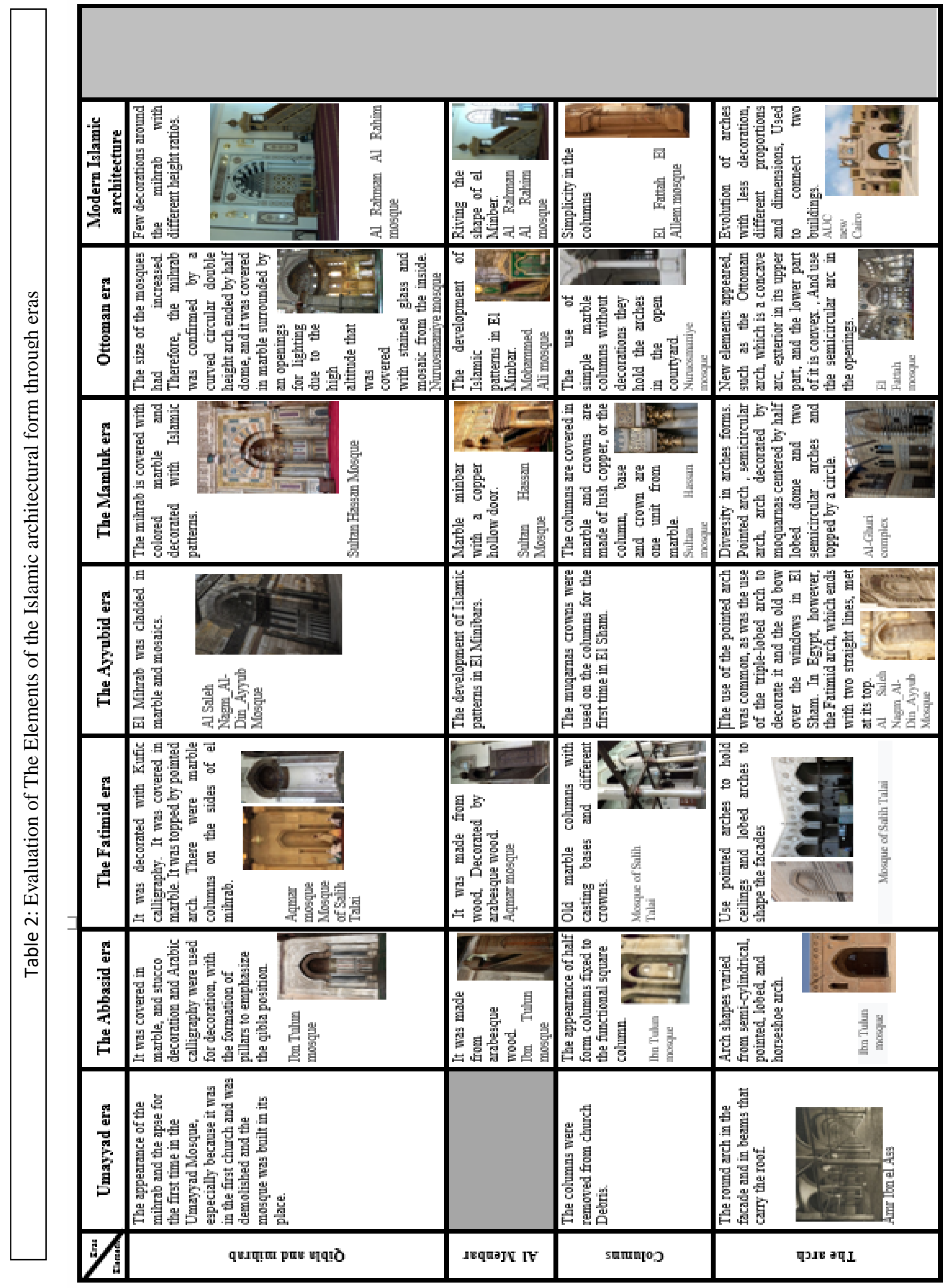




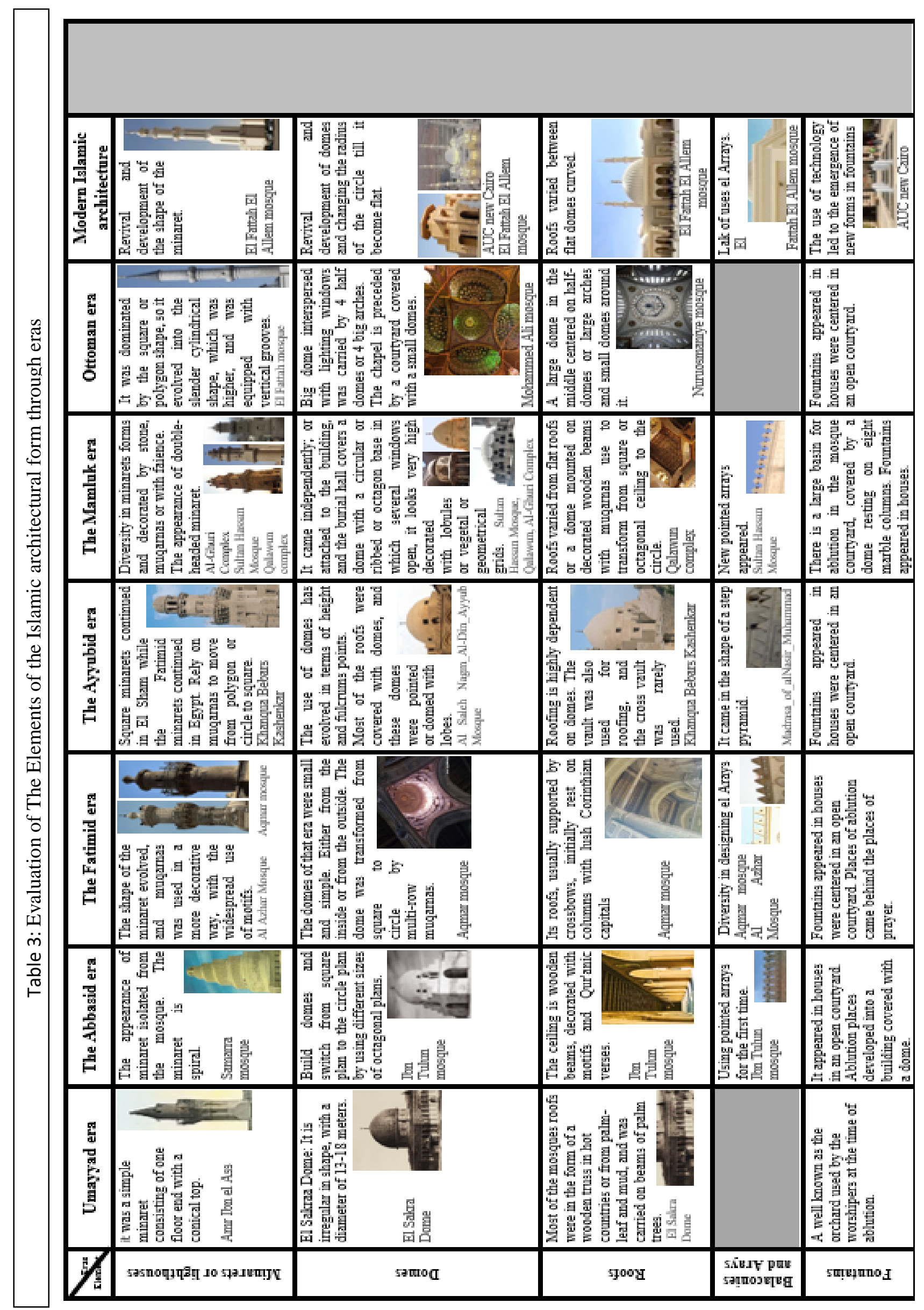




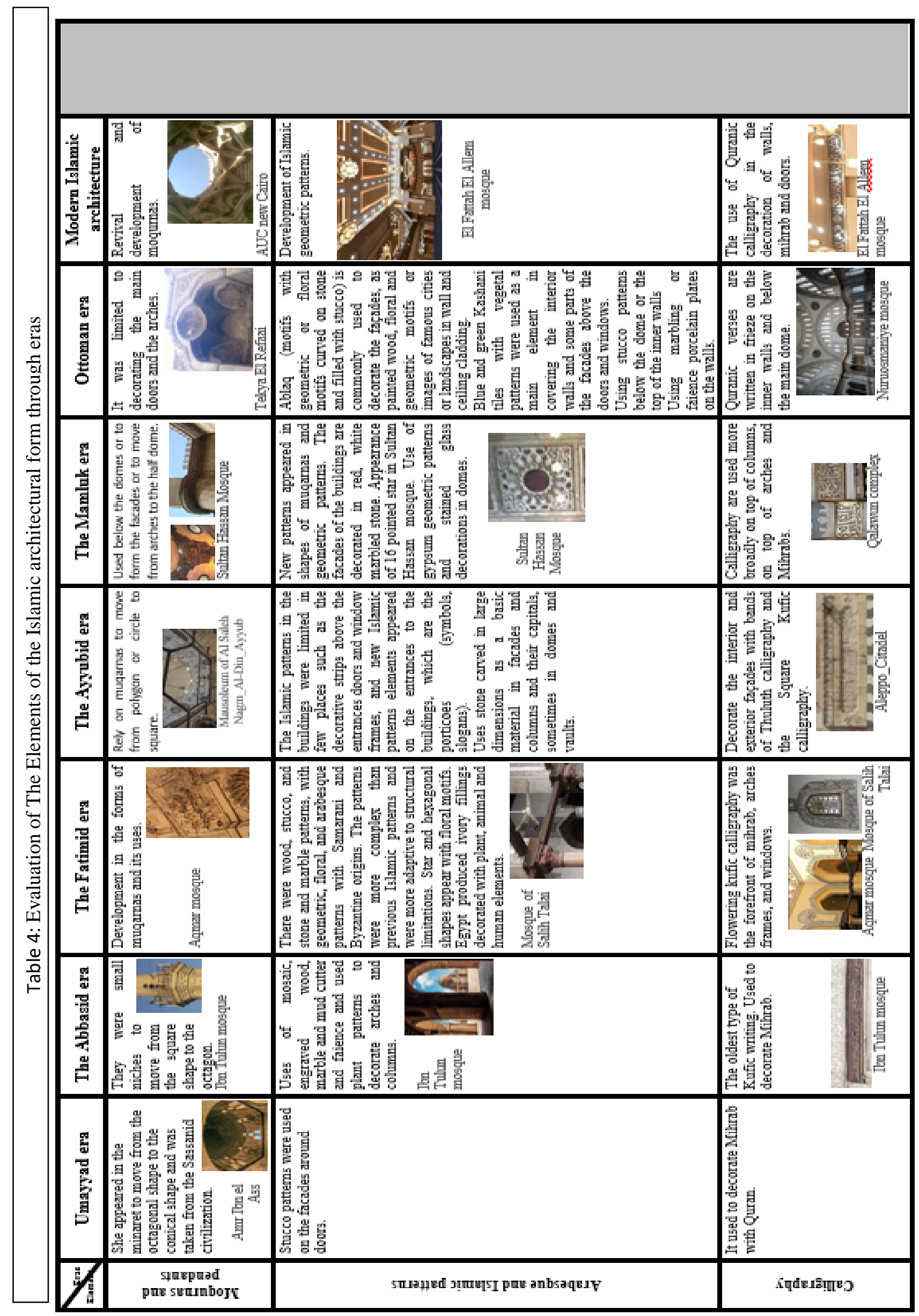




\section{(4/1/1) Evaluation from the previous study (The principles of designing the Islamic elements):}

From the previous analysis we can find that there are some features that sustained through eras for each element.

- The Gates: they are two high towers from the rest of the building and are linked together by a form object (frieze or shade ...) or functional (corridor or rooms).

- Entrances and Doors: The doors are decorated, surrounded by an arch that relief and higher from the rest of the building.

- Windows: Covered with blank wood and glass topped by an arch, or the window itself is an arch.

- Mashrabiyat: It covers windows and is made of hollow wood or arabesque, and is used for a functional purpose first, then formative second.

- Qibla and mihrab: It is a circular arch curved inside.

- Minbar: It consists of an ornate door and ascend the stairs to the top of the platform on which the Sheikh stand.

- Columns: Used to transfer loads from arches, whether internal or external.

- Arches: Used for formation purpose around doors and windows or functional to move loads from the ceiling to the columns and used in the inner corridors or covered outer corridors.

- Minarets or lighthouses: One of the most important architectural elements in the design of the mosque, they are either separate or connected to the mosque and graduate in size and thickness until they end with one point from the top.

- Domes: One of the most important architectural elements it is radius and height changes may be it stand on neck or not it found in the center of the building.

- Roofs: may be domes or flats with Islamic patterns from inside.

- Arrays: it is an element which can be dispensed.

- Fountains: it is an important geometric elements in houses or palaces.

- Moqurnas: It is a decorative element that distinguishes Islamic architecture and is found at the bottom of domes or in the minarets to transform from a square surface to a circular or octagonal, or vice versa, one unit is shaped of an arch curved inside so we can many forms from it by increasing or decreasing it is unit or putting it in different places.

- Islamic patterns and Arabesque: It is an important form component used to add aesthetic element to the building. domes.

- Calligraphy: It is used to write Quranic verses on the walls, around doors, windows, and inside

From the above we distinguished that in designing Islamic elements its shape must be symmetry around its axes, regularity, and repetition, straight lines, right angles, corners, and simple repetition of elements and patterns must be found.

The changes in construction methods compatible with the contemporary possibilities and the new building materials available in the same place with the cultural and social constants of the Islamic religion will produce new Modern architecture elements that expresses the contemporary of new building materials and methods and the authenticity of heritage values and the social values of Islamic society

Islamic architectural theory is a universal theory of all time and place, rather than a local theory that emanated in a particular place and time. It is a theory that works to deal with variables for every time and place.

So we will study the Islamic geometric patterns which the parametric algorithms redesigned them and re-represented in contemporary design to know the changes that happened to them and how it extracted new pattern from the old one. 


\section{(4/2) The Islamic geometric patterns}

The Islamic geometric patterns derived from Islamic art. Many Islamic designs are built on squares and circles, typically repeated, overlapped and interlaced to form intricate and complex Patterns. In ancient times Muslims did not have books in which models of these motifs were described. Recently it explained as a system in which these geometric networks were divided into identical units that are repeated in regular order. This method has helped in the process of enlarging and minimizing the decorative schemes easily based on the relative relationship between the geometric shapes. The complexity and variety of patterns used evolved from simple stars and lozenges in the ninth century, through a variety of 6- to 13-point patterns by the 13th century and finally to include also 14- and 16point stars in the sixteenth century. Artist and educator Roman Verostko argues that such constructions are in effect algorithms, making Islamic geometric patterns forerunners of modern algorithmic art ${ }^{(5)}$.

\section{(4/2/1) Analysis of Islamic Geometric Patterns (IGP)}

According to many researches had divided the IGP into:

The Cell: The seed geometry or basic unit for the pattern which we will call the cell; and arrangement or tessellation which is the actual pattern generated by the repetition of the cell in one of the 17 plane symmetry groups.

Fig.1: The basic unit (the Cell)

The Fundamental Unit: In most cases, it is possible to examine the IGP cells and find symmetry within the geometry of the cell. It is also possible to dissect the cell into smaller units until the non-symmetrical part is found ${ }^{(6)}$.

\section{$(4 / 2 / 2)$ The extraction of new from traditional}

Many researches have analyzing the geometry of the IGP that

Fig.2: The Fundamental Unit made an analysis by isolating cells and populating them to reconstruct the corresponding pattern. Recently designers have used this knowledge to create modern versions of IGP designs from scratch (6). 


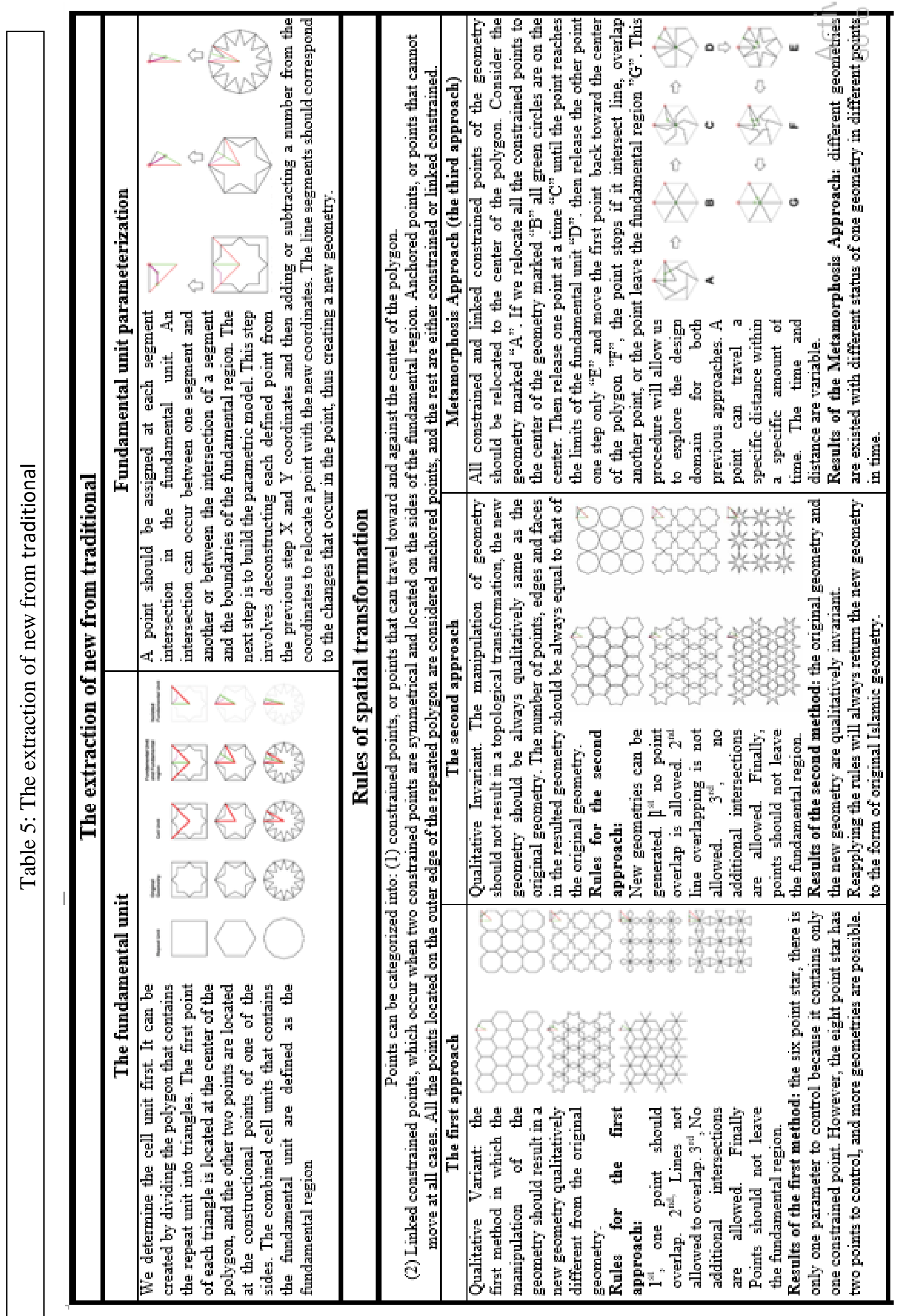




\section{(4/2/3) During the research we have revealed that:}

- The first step is to isolate the cell to delineate the fundamental unit. The fundamental unit is found by decomposing the cell to its constructional non repeating components. This operation will generate a fundamental unit for the pattern, which is defined as the minimum motif that cannot be reached with symmetry. Once the fundamental unit is attained we proceed to reconstruct its geometry with a parametric model. A geometrical construct with variable attributes (properties) that allows the exploration of design variations with ease. By defining certain rules that govern the parameters. The designer can to explore the patterns in a manual manner.

- Islamic geometric patterns have simple strict rules for creation and have infinite number of possible patterns.

- Can be metamorphosis into contemporary Islamic patterns that follow parametric architecture.

- Patterns can be used to emphasize cultural characteristics, and determining identity.

So we will study parametric architecture to identify them to develop an Islamic principles using parametric algorithms.

\section{5- How could parametric design affect Islamic architecture?}

Parametric design existed before our digital times. To design the church of Sagrada Família, Gaudí created an upside-down model, using strings weighed down by birdshot. A mirror placed below the model showed what the chapel would look like right side up ${ }^{(7)}$.

\section{(5/1) Parametric Design}

It is one of the designs that was born with the digital system and its applied software to rethink the architectural design according to a numerical system. It allows the computer to deal with an algorithm system. It used mainly to design shapes, structures that respond to the general concept, to their environment, climatic issues and contextual features. Parametric design relies on control of 3D modeled components through modification of certain parameters of a building model. These modifications are driven by mathematical formulas, data values, numbers or specific computer algorithms rather than manual changes of the model properties ${ }^{(8)}$.

\section{(5/2) How the parametric model operates?}

Parametric design form is shaped by values of parameters and equations are used to describe the relationships between the forms. We can distinguish between: CONCEPTUAL parametric design: It is the parameters of a particular design that are declared, not its shape. By assigning different values to the parameters different objects or configurations can be easily created. This design method requires knowledge of programming or scripting and it is inherent of the mathematical algorithms whereby interactive design is not possible. And CONSTRUCTIVE parametric design: Refers to data embedded within a predetermined 3D object. This parametric concept is realized in various CAD packages like Autodesk Revit... Instead of drawing lines, arcs, etc. designers can insert pre-drawn components, doors, windows, load elements, stairs or roofs etc. This results in 3D models instead of 2D drawings ${ }^{(9)}$. 


\section{(5/3) Shapes of Parametric Design}

\section{(5/3/1) Voronoi diagrams}

The Voronoi diagram is a system that divides the space into sub-spaces in an organic way. The diagram uses points to create cells that surround these points. Points can be placed as spontaneously or can be determined in the direction of a certain data and tessellation can be provided accordingly. The first use was seen in the disposition of the solar system and its environs. In 1854 Dr. John Snow used Voronoi diagrams effectively to detect the Broad Street Pump causing the cholera outbreak ${ }^{(10)}$.
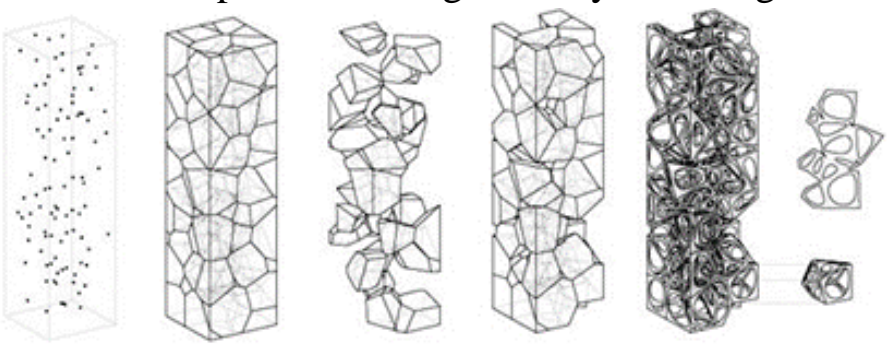

Fig.3: Steps of Voronoi diagrams in 3D

\section{The Concept of Voronoi}

Given a set of a finite number of distinct points in the $2 \mathrm{D}$ or in $3 \mathrm{D}$ : is to draw a line connecting adjacent point, to draw a perpendicular line to the one you just drew in the midpoint of it, to connect lines drawn in the second step into a network.

\section{Voronoi Diagrams Elements}

A simple voronoi diagram has the following elements: Voronoi vertex, Voronoi cell, Voronoi space, Voronoi foam ${ }^{(10)}$.

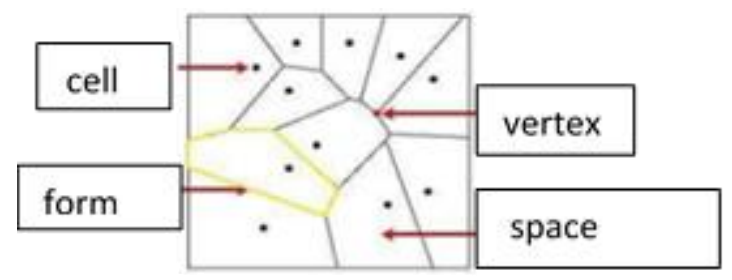

\section{Voronoi application}

Fig.4: Voronoi Diagrams Elements

Voronoi can be implemented in generative forms to save the time for Architects and Designers. There are many application: space filler, structural communication, urban planning, and sustainable tool in planning, landscape ecology, modulator, spatial customization, pattern generators, and proximity matrix developer and as navigator in $\operatorname{GIS}^{(10)}$.

\section{Dimensional study of voronoi}

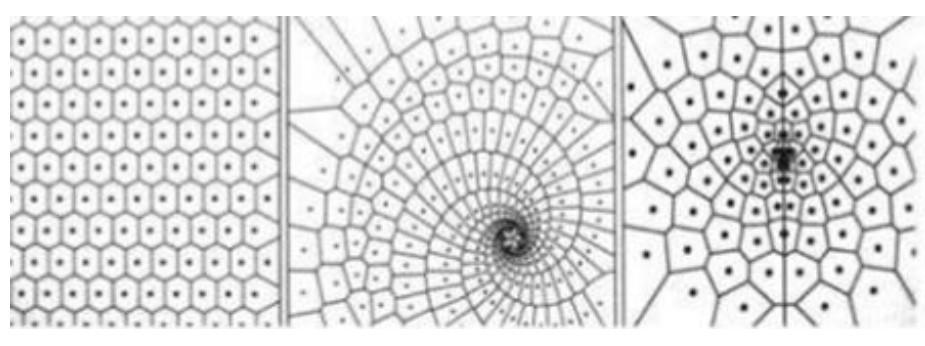

Fig.5: Dimensional study of voronoi One dimensional

Voronoi tiles have been created by a series of points. A cellular pattern that each of these cells includes the space surrounding the point. Place of the rest of the shapes created with these pattern fits into a close system. They form a collection of shapes that look like square, honeycombs, crystals or boulders. One dimensional: These irregular tessellations on a plane occur spontaneously in nature at every scale

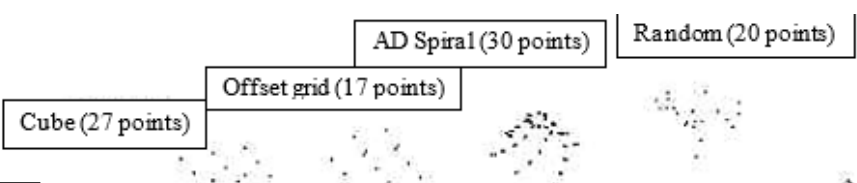

Fig.6: Two dimensional to three dimensional
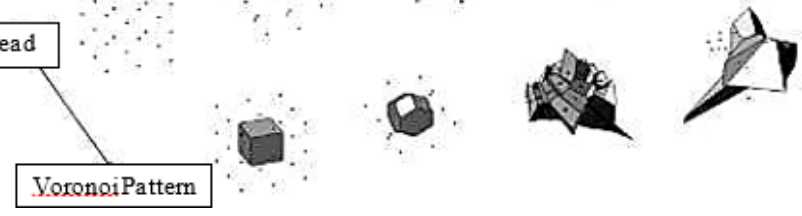
Two dimensional to three dimensional: The minimal enclosure system of these bubbles and cells shows that tilings are a simple system, rather their thickness in three dimensions expands constructive towards infinity without any gaps ${ }^{(10)}$.

Table 6: Voronoi example

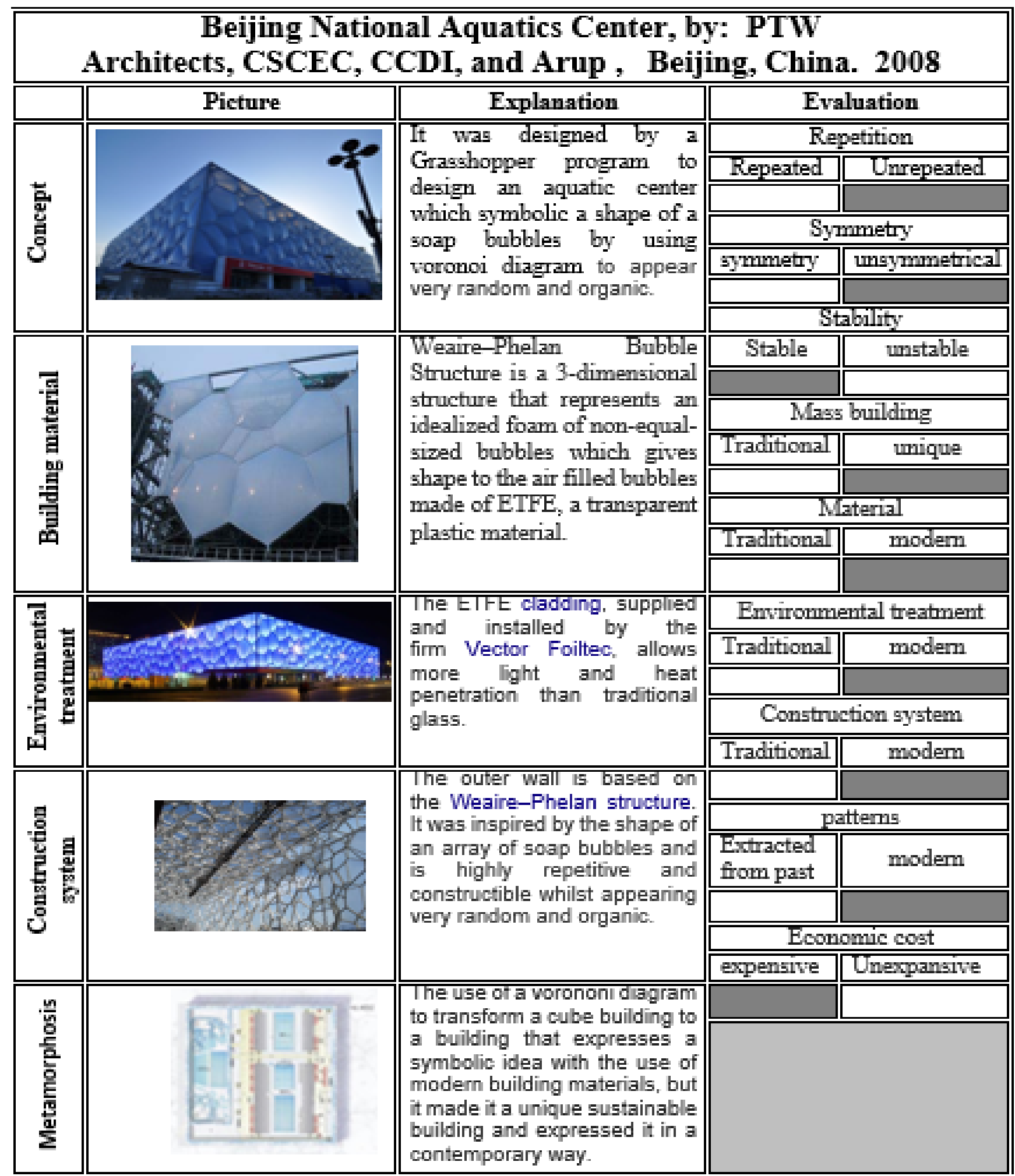




\section{(5/3/2) Ripples}

It's an interactive installation designed with the purpose of engaging passers-by through animating still sculptures. "ZEBRA", a plug-in for Rhino developed by the Cypriot company "Seamlexity", is implemented to facilitate the design and digital fabrication processes ${ }^{(11)}$.

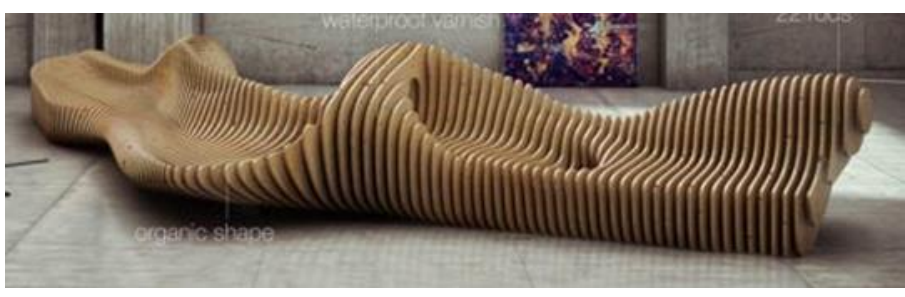

Fig.7: Parametric Bench - Interior Design by Oleg Soroko

Table 7: Ripple example

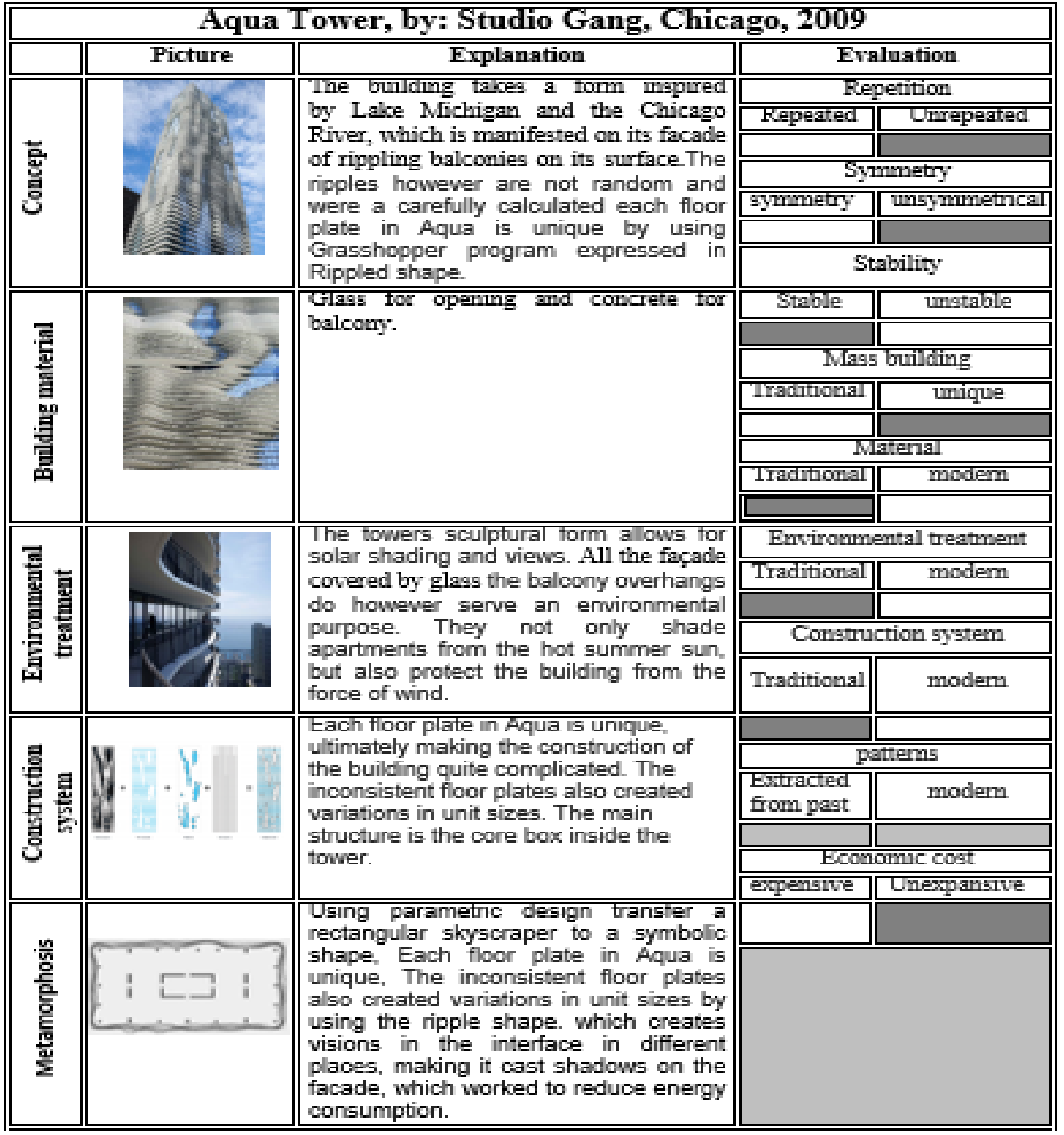


(5/3/3) Zome system

A structure emerging from the combination of a dome and zonohedron ${ }^{(11) .}$
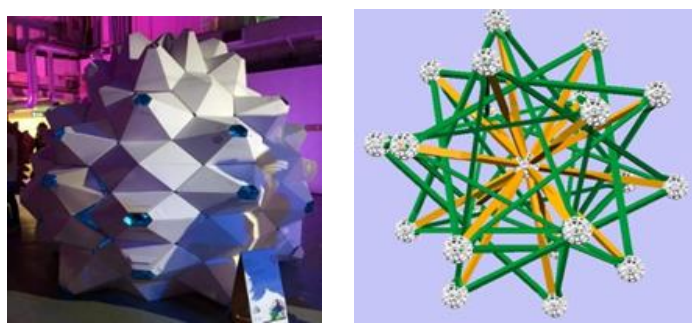

Fig.8: Zome system, geodesic domes

Table 8: Zome example

\begin{tabular}{|c|c|c|c|c|}
\hline \multicolumn{5}{|c|}{ Daystar zome, Zonotopia City, San Francisco, 2013} \\
\hline & Picture & Explanation & \multicolumn{2}{|c|}{ Evaluation } \\
\hline \multirow{5}{*}{ 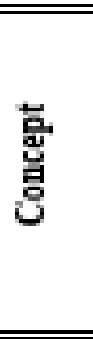 } & \multirow{5}{*}{$\begin{array}{l}28 \\
82\end{array}$} & \multirow{5}{*}{$\begin{array}{l}\text { Exterior ghade structure, archway } \\
\text { entrance }\end{array}$} & \multicolumn{2}{|c|}{ Repetition } \\
\hline & & & Fepeated & Urirepeated \\
\hline & & & \multicolumn{2}{|c|}{ Symmetry } \\
\hline & & & symmetry & unsymmetical \\
\hline & & & \multicolumn{2}{|c|}{ Stability } \\
\hline \multirow{3}{*}{ 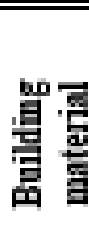 } & & \multirow{3}{*}{$\begin{array}{l}\text { Wooden tiled floor and all the zome } \\
\text { made from wood. }\end{array}$} & Stable & unstable \\
\hline & & & \multicolumn{2}{|c|}{ Mass building } \\
\hline & & & Traditional & unique \\
\hline \multirow{4}{*}{ 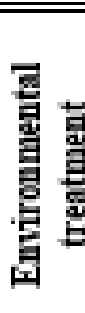 } & & \multirow{4}{*}{$\begin{array}{l}\text { Lighted by UV (LFD) light ingide it. } \\
\text { Contain circle and owal holes in each } \\
\text { panel to penetrate sum light and be a } \\
\text { natural ventilation. }\end{array}$} & \multicolumn{2}{|c|}{$\overline{\text { Material }}$} \\
\hline & & & Traditional & modem \\
\hline & & & Environm & ntal treatment \\
\hline & & & Traditional & modern \\
\hline \multirow{5}{*}{ 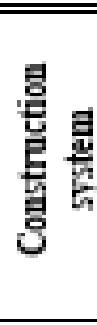 } & & \multirow{5}{*}{$\begin{array}{l}\text { It built from a single wood diamond } \\
\text { gheet with a circular or oval hole } \\
\text { inside it and connected together from } \\
\text { the vertex by a cose wooden panels } \\
\text { till they closed at the top of the zome. }\end{array}$} & & \\
\hline & & & Constrn & tion system \\
\hline & & & Traditional & modem \\
\hline & & & & 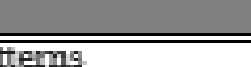 \\
\hline & & & $\begin{array}{l}\text { Exiracted } \\
\text { from past }\end{array}$ & modern \\
\hline \multirow{4}{*}{ 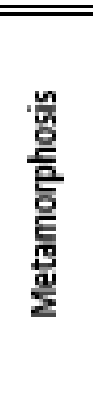 } & & \multirow{4}{*}{$\begin{array}{l}\text { Hexagonal fioor meet at the top to } \\
\text { form zome. } \\
\text { The hexagonal ghape tranafer into } \\
\text { the ghape of a pointed dome using } \\
\text { the zome style with its use to make } \\
\text { extemal rest rooms or chalets that are } \\
\text { easy to remove and ingtall. } \\
\text { Zoom was also used to develop the } \\
\text { old dome shape and use it in a new } \\
\text { way. }\end{array}$} & \multirow{2}{*}{\multicolumn{2}{|c|}{ Economic cast }} \\
\hline & & & & \\
\hline & & & & \\
\hline & & & & \\
\hline
\end{tabular}


(5/3/4) Flex shell : Grid shells are efficient lightweight structures that are shaped to purely correspond to the forces of nature ${ }^{(11)}$.

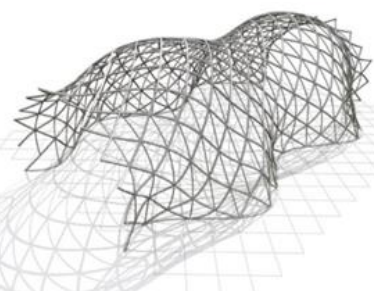

Fig.9: Flex shell

Table 9: Flex shell example

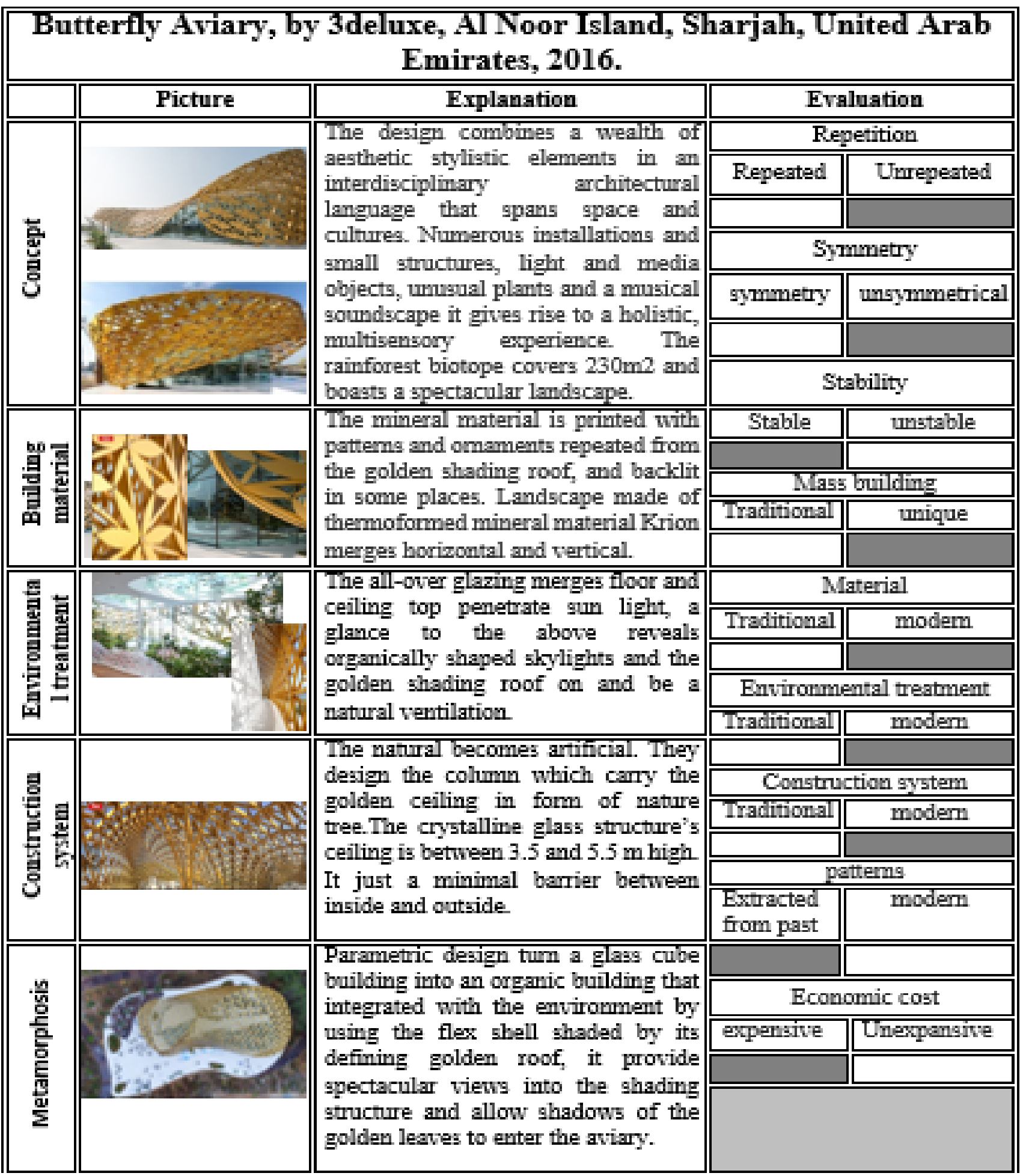


(5/3/5) 3-dimesnional pattern: It creates as tessellated tile. The tile was modeled in Rhinoceros 3D ${ }^{(11)}$.

Fig.10: 3-dimesnional pattern

Table 10: 3-Dimensional example

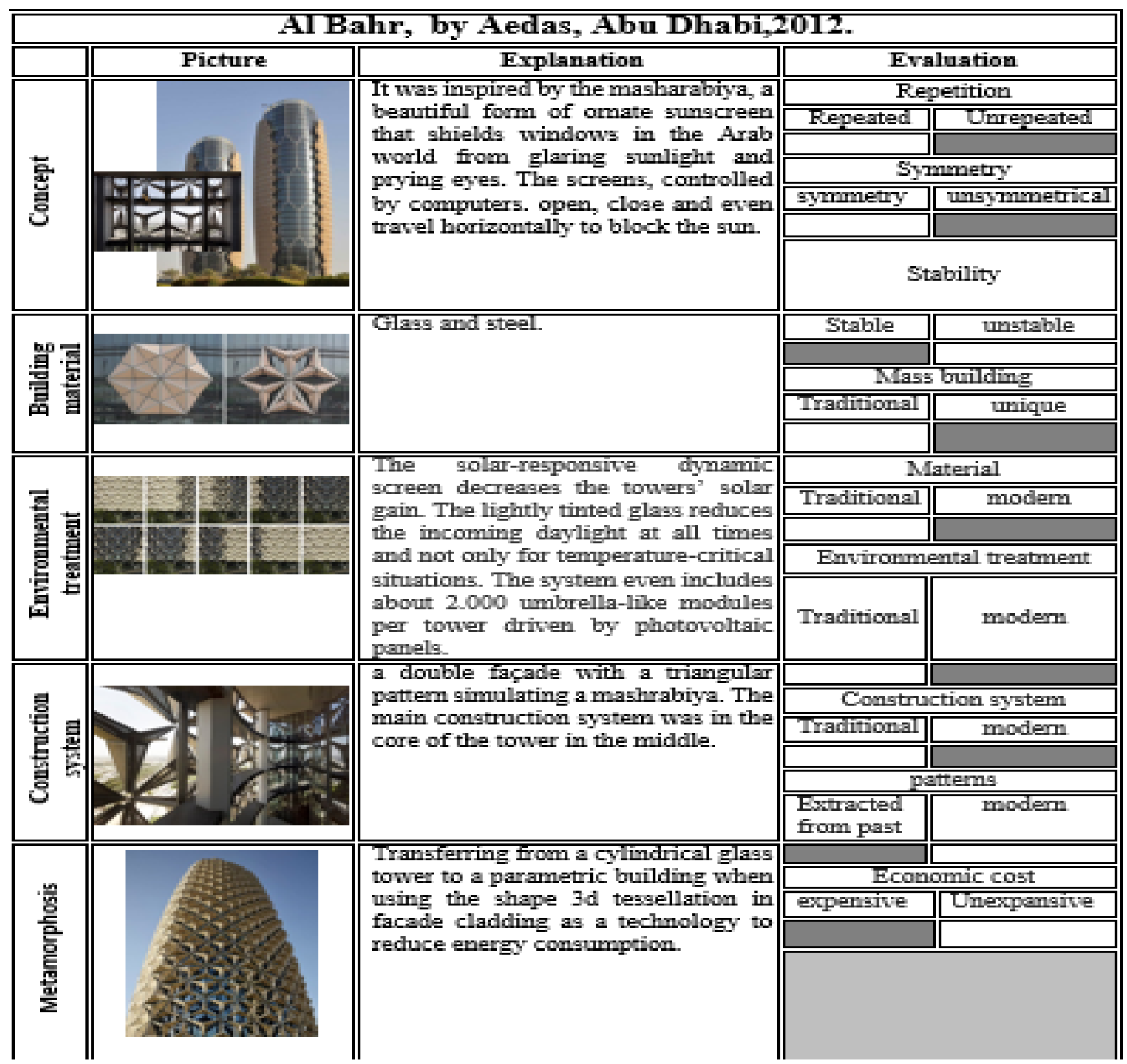




\section{(5/4) The Evaluation of the shapes of parametric architecture (the principles of parametric architecture) are:}

From the previous analysis study of the shapes of parametric design we obtained the principles of parametric architecture.

- Parametric design is a technique that can be used with any trends of the architecture.

- When it used with any trends, it changes the shape of the building to a contemporary one and also appropriate the environment.

- It is considered one of the most sustainable designs by using traditional environmental treatment by using the Islamic environmental treatment but in contemporary way and by using new technology and material .

- It gives more aesthetic shape to the building, making the building express the culture of the city in it or a symbolic idea.

- Using modern and old building materials in a different and modern style tends to a new modern design.

- Inspiration of Islamic tessellation and represented it in a contemporary tessellation.

- Conclusion based on Evaluation:

- Parametricism means no more axes, no more regularity, and no more symmetry nothing that smacks of the great architecture of the past. "Avoid repetition, avoid straight lines, avoid right angles, avoid corners, and avoid simple repetition of elements.

\section{6- Conclusion}

\section{From this research we found that the Islamic principles had affected by the parametric principles and some changed and some disappeared like:}

\section{Islamic principles which upgraded:}

- The parametric principles affected the Islamic principles in its Construction system and changed it so the construction system of the buildings are Contemporary modern.

- The building materials of the Islamic buildings changed from tradional one to Contemporary modern one which affected by parametric principles.

- The Presence of the Islamic elements but in symbolic parametric shape.

- The mass building of Islamic design affected by parametric principles and become unique it means not repeated and become modern one.

- Parametric principles respect sustainability and environmental treatment of Islamic principles so it re-represented it in Contemporary modern design.

- Parametric principles redesigned the Islamic patterns and changed them in a contemporary design which fits the modern design of the building.

\section{Islamic principles which still the same:}

- The mass buildings still symmetry and stable in some building which it looks like the old one from the first sight.

- The Islamic character of the buildings are compatible with the surrounding environment so parametric design affected by it and use it in design the buildings.

\section{Islamic principles which neglected:}

- The shape of the parametric buildings not follow the function of the them while Islamic design the shape must follow function so parametric design affected Islamic design so the shape of the parametric Islamic buildings not follow function. 
Finally this means that:

- The Islamic parametric building must extracting from the past Islamic architecture.

- When parametric algorithms used with Islamic architecture changed in shape not in the principles of its element.

- Islamic architecture can be contemporary, progressive and inclusive but, above all, can act as a beacon of hope in opposition to nihilistic conflict that has gripped the Middle East region.

\section{7- References}

\section{First: Arabic reference}

$$
\begin{aligned}
& \text { 1- ـ أ .د/ عبد الباقي إبراهيم وشركاه ، مقال بعنوان "مراحل تطور العمارة في مصر في العصر الإسلامي" ، رئيس مركز } \\
& \text { الدراساتـ التخطيطية والمعمارية ورئيس تحرير مجلة عالم البناء، علي الموقع الالكتروني لمركز الدراسات التئية التخطيطية }
\end{aligned}
$$

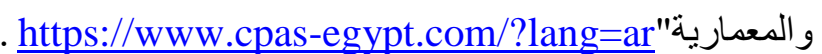

$$
\begin{aligned}
& \text { 2- الدكتور / عبد الباقى إبر اهيم ، مقال بعنوان "الأصالة و المعاصرة فى العمارة الإسلامية "، رئيس مركز الدراسات }
\end{aligned}
$$

.https://www.cpas-egypt.com/?lang=ar

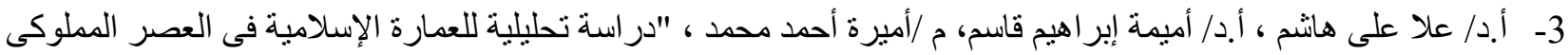

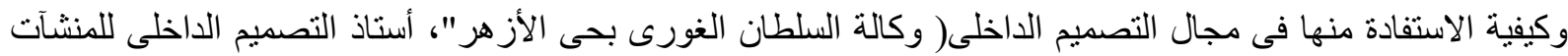

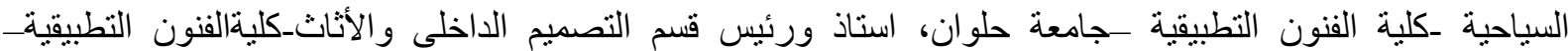

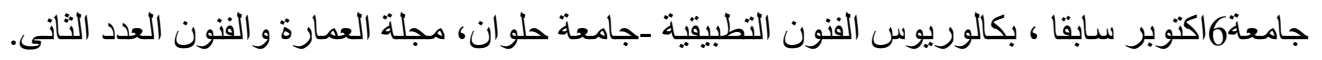

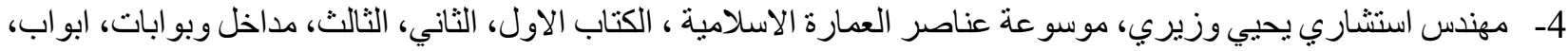

\section{Second: English reference}

شبابيك، مشربيات، خرط خشبي، الناشر مكتبة مدبولي، منوري، 1999.

5- Ahad Nejad Ebrahimi, Minou Gharehbaglou and Morteza Aliabadi,"Parametric Design pattern Language and Geometric Patterns in Historical Domes in Persian Architecture", Article in Ciência e Técnica Vitivinícola, January 2014.

6- Mostafa Alani, Carlos Barrios, "parametric metamorphosis of Islamic geometric patterns: The extraction of new from traditional", Clemson University, 2015.

7- Christina Robev, Robazzo Design studio LTd, "What is parametric design? "2018.

8- Michail Georgiou, Odysseas Georgiou, "Parametric design generative architecture" annual competition in University Nicosia, Cyprus, 2016.

9- Yahya Abd Alla Hiand Mohamed Rashid Bin Embi, 'Evolution of Islamic Geometric Patterns', Research article, Faculty of Built Enviroment, Universiti Teknologi Malaysia, 2013.

10- Ali ŞAHIN1, Betül HATIPOĞLU ŞAHİN2, " Examining the use of Voronoi diagrams in architecture on a student project", 3rd International Conference on New Trends in Architecture and Interior Design, HELSINKI, FINLAND, 2017.

11- Michail Georgiou, Odysseas Georgiou, "Parametric design+ generative architecture", annual competition in University Nicosia, Cyprus, 2016. 